\title{
Cult Social Prevention Under Psychological Perspective
}

\author{
Guiyang Xiea, Meifu Yana, Qizhen Liu ${ }^{a}$
}

\begin{abstract}
The breeding and communication of cult are all realized on the base of psychological activities, psychological factors play an important role in preventing and resisting breeding and communication of cult, and in this paper, it demonstrates respectively at this point, and starts from forming the long-term mechanism of the Chinese cult governance and proposes the conception and specific suggestions accordingly of establishing the national psychological assistance system to prevent and resist breeding and communication of cult.
\end{abstract}

\section{Keywords}

Psychological assistance, Archimedes Effect, Threshold Phenomenon, community life, internal incentive

Because the breeding, multiplication, communication, and expansion of cult will all be realized with the help of psychological laws, therefore, widespread psychological assistance system is suggested to be established so as to defuse the psychological cruxes of the special groups during the social reforms, and block out the breeding, multiplication, communication, and expansion of cult and prevent and resist the inroads of cult.

\section{ROOTS OF THE CULT FOLLOWERS' CULT BELIEFS ARE IN PSYCHOLOGY}

Why would the cult followers be so crazy in believing cult? All the deep reasons are in psychology, and caused by the psychological factors.

\section{Believing in Cult for the Influences of Cognitive Factors}

Man's understanding of the world and development of science is an asymptotic process as well as an everlasting process. Human being is incapable of completely revealing all natural and social sophistications no matter how high their cognitive level has been raised and how developed science becomes. This is because man's understanding of the world has always been that more unknown mysteries will appear once an unknown mystery is proved, and this is how the human being's recognition and development of science have evolved step-by-step. Science never talks nonsense about phenomena that have not been proved by research; while cult on the contrary, it could fabricate various fallacies to make arbitrary interpretations on the known unsolved mysteries in the meantime of calling itself God and Buddha. What's more, the followers will not and dare not have any question to their lies because the cult leaders are so unscrupulous to describe themselves as omniscient and omnipotent masters of the universe, and therefore,

aHubei University, Wuhan, China

\section{Correspondent Author:}

Qizhen Liu, Psychology Department, Hubei University, Wuhan, China 
many people become loyal cult followers in cognition like this just because of long-term absence of scientific interpretations on some natural phenomena.

\section{Believing in Cult for Influences of Emotional Factors}

Another psychological factor leading people to believe in cult is emotion. According to data, many cult followers have an emotional wasteland deep inside their hearts, and their believing in cult is the result of seeking emotional haven because of family misfortunes, emotional breakdown between husband and wife, disharmonious sexual life, emotional frustrations, etc. The authors once contacted with a young workman who believed in cult to seek emotional sustenance because of love failure. She had a stronger emotional need during her growth process and longed for love, however she had always been kind of self-contemptuous, and thought herself not as beautiful and excellent as they were in comparison with other outstanding females, therefore she was lack of courage to express her feelings and pursue love. She once fell in love with an excellent boy in class secretly when she was in specialized secondary school, and however, she dared not to lay bare her heart but often had some romantic illusions with this boy and daydream with such contents, enduring the tortures of self-contempt and agony, she finally took heart of grace to express her love to him, only to find he had already got a girlfriend much more excellent than her. This emotional experience left pretty deep marks in her mind, and further deepened her self-contemptuous psychology. Love frustration and sense of self-contempt led to desperation for the future home of love, and made her a follower of Falun Gong Cult.

\section{Believing in Cult for the Influences of Factors of Pursuing Personality Perfection}

Many people contacted with and finally believed in cult out of self-cultivation, moral promotion, and sublimation of spirit. This kind of need is especially obviously strong on people who have higher cultural qualities and have understanding of certain degree to the value and significance of life and have good expectations for life. Such people are always cynical and cannot bear the thought of people who are trying hard to gain fames and fortunes; they detest and despise those spoony people who are obsessed with romance because they are incapable of understanding thoroughly this and next life, all these psychological conflicts and contradictions leave them no inner peace. So when cult sings loudly of truth kindness and tolerance and being the good person, this kind of people might be bewildered by heretical ideas wrapped in beautiful coats, and fall into the abysses set up by cults and it is hard to extricate themselves.

Once we figure out this point, it is not difficult to understand that why cults could make ordinary rural and urban people believe in them and also be capable of developing their organizations in institutions of higher learning, scientific research institutes, and party and government departments.

\section{Being Obsessed With Cult for the Influences of Factors of Psychological Frustrations}

There are many people who have felt the dangers and unpredictability of man's hearts, and experienced fickleness of worldly relationship between man and man, snobbery of the world, and have no confidence in future because of suffering setbacks in career, life, work, and family, they have lost their proper faith in society and life, and get themselves stuck in the psychological state of resentment, self-accusation, complaint, loneliness, and empty. Such people are desperate for psychological concerns and cares, so when cults wave to them at the right time, and offer them petty favors and warms exclusive to the cult groups, and tell them there is a "Falun World" having no frustrations and pains but joys and happiness, these people will throw themselves into the arms of cults without hesitation.

All these have showed that people are driven to 
believe in cults by psychological factors all without exception, but cults' utilization of psychology is far more than these.

\section{CULTS COMMUNICATE AND SPREAD THROUGH PSYCHOLOGICAL APPROACH}

The reason why cults could communicate and develop so fast is mainly because the cult leaders have made wide application of psychological laws to serve their cult establishment and missionization. And psychological laws most commonly used by cults include:

\section{Developing Cult Organization by Using the "Threshold Phenomenon"}

The "Threshold Phenomenon" is also known as the "More Will Have More Effect", and in social psychology, it means when you are intended to ask someone to help you with a big event, you should never make your requirements all at once, which will scare him away, instead you should make a smaller requirement and gradually raise the quota after he has reached the requirement and drawn some benefit from it, till one day he will unconsciously accept your entire requirements.

All cults use the "Threshold Phenomenon" during the development of cult organizations. For example, Li Hongzhi did not use his "Falun Dafa" to recruit followers, nor did he dress himself up as the largest Buddha in the universe, he only propagandized that practicing Falungong could purify bodies, ward off diseases, build up good physiques, and eliminate disasters so as to allure others to enter his trap. It was with the help of this psychological strategy that he managed to develop millions of followers within just a few years.

\section{Developing and Consolidating Cult}

Organizations by Using the Group Psychological Laws

Recruit followers because groups could provide sense of security for members. Because the cult leaders are all aware of the psychological law that loneliness inspires fear, so they require collective learning of scriptures and collective practice by the followers, so as to attract more people to join in the cult, making use of the group psychological characteristic that cult groups could provide sense of security for members.

Cult groups make the followers tenaciously defend the cult by taking advantage that groups could satisfy members' affiliation need. Aristoteles said: "Human is social animal". All of them have the psychological need of social affiliation. However in the present society, some social members' affiliation needs failed to be properly satisfied due to the influence of market economy as well as increasingly fierce competitions in various fields of social life, therefore, cult will aim at this kind of population, and take the advantage to get in, and allure them to enter its cages by using the characteristic that cult groups could satisfy members' affiliation need.

Cults hypnotize the followers by using that groups could satisfy members' self-confirmation need. Everyone has the self-confirmation need, and however, such need could only be satisfied in groups. When many people do not play their previous glamorous roles any longer in the social transition period, or feel self-contemptuous, sentimental, and resentful because they do not own their previous statuses and identities; cult claims that it is capable of making him regain the self-confirmation: Which means to happily join in cult in the intoxication of feeling themselves like practitioners and will immediately become Buddha, God, and great man.

Cults recruit followers by using that the groups could satisfy members' self-respect need. Self-respect is an advanced need of mankind, which could not be satisfied without groups. The cult organizations make followers regard themselves as someone beyond the ordinary people and someone who are very lofty and noble, and regard those who do not believe in cult as wretches, trashes, and even devils that are totally at 
the different levels with them, so as to recruit those penniless, powerless members of weak groups with low social statuses.

The cult leaders inspire followers by using that "group life" could increase the members' confidences. This refers to that when some followers are intended to give up practice when they discover they are deceived; some discover it is not easy or even impossible to become Buddha or God through practice, the cult leaders will resort to the magic key of "having group life". The specific way is to let the followers who learn well to speak out the practice effects such as "I have opened my heavenly eye", "I am not sick any more" during the group activities so as to increase the confidences of those seceders. Since he could make it, I will do the same one day; arousing worship and reverence. They will believe that masters are really gods; producing group psychology, which means that they will believe that their diseases are removed once they accept the indications; having the "Emperor's New Clothes" phenomenon, which means the four reactions such as false declaration of practice effect under the effect of group pressure so as to stabilize and strengthen the cult organizations.

Make external pressure to enhance the internal cohesion of cult. According to the research of psychology, violation, attack, competition, and threat pressure from outside the groups could enhance the internal cohesion of the groups, and cult organizations make full use of such law to enhance their internal cohesions by continuously using an excuse of government persecutions. The organizers' direct purpose of the "April 25th Event" happened in Mainland China lied here.

\section{Developing Cult Organizations by Turning Followers Into Cult Psychotics Through Psychological Approach}

Make the followers communicate cult voluntarily by using the worship for cult leaders. It means that the cult leaders establish their images of gods with boundless supernatural powers by means of self-praise, deceit, and threatening, widely applied indications so that the followers will completely lose independent autonomous consciousness and rational discretion, and ordered by cult like robots, and communicate cult like they are bewitched.

Urge them to do missionary work by using followers' need of desires to enter the Kingdom of Heaven. Just like the terrorist organizations convince the terrorists that martyrs will go to heaven, and there will be 72 virgins for them so they would serve as "suicide bombers", the followers who want to enter the Kingdom of Heaven will tirelessly communicate cult according to the cult leaders' instruction that one more person you release, you gain yourself one more piece of merits and virtues, you are one more step closer to "the Kingdom of Heaven".

Push them to do missionary work by using the followers' "Archimedes Effect". "Archimedes Effect" refers to an emotional state that how you wish you could tell everyone about your discoveries just like the ancient Greek scientist Archimedes went wild with joy after he had discovered the "Archimedes Law" in physics.

When the cult followers believe in the cult leaders' instructions, and believe that they have found a way to heaven, they will become the same with Archimedes in emotion and insanely do missionary works with everyone they meet.

Drive the followers to do missionary work by skillfully using excitation. Different from the common excitation methods of money award and certificate of reward, cults award the followers that they could enter the Kingdom of Heaven if they practice well. This is a promise that cannot be fulfilled as long as you are alive, and this is virtual and blind goal that cannot be inspected whether it has be fulfilled, while "If one decides to devote his entire life to a virtual and blind goal which is doomed not to be fulfilled, there is no failure to be spoken of". People inspired by such invincibility will stay in the self-experience of success 
forever, and it is such experience that inspires the cult followers to communicate cults tirelessly and insanely.

Make followers voluntarily do missionary work with the help of internal excitation. Intrinsic (internal) excitation is a kind of excitation applied with the aim of man's internal motivation, and it is an excitation method whose activity results enable people to generate emotions such as sense of honor, sense of pride, and sense of happiness in psychology, so as to self-reward or remuneration, and produce the motivation of "I want to do it", so they could always enjoy carrying out such activity without no demand of external rewards.

It seems that all the cult leaders understand this psychological principle, and it is on the intrinsic excitation that they have depended to make the followers work hard to communicate cults for them without asking anything for return.

\section{ESTABLISHING THE PSYCHOLOGICAL ASSISTANCE SYSTEM TO PREVENT AND RESIST BREEDING AND COMMUNICATION OF CULT}

\section{Functions of Psychological Assistance in Preventing and Resisting Breeding and Communication of Cult}

Psychological assistance could help people ease the inner pains. Cults will provide them a path to relieve pains: One is that believing that cult could cure all diseases; the other is that they can be taken into another space, the blissful world of Kingdom of Heaven where there are only joys without pains when people might suffer from frustrations in life; or fail to obtain comforts for psychic trauma; or find no way out because of mental vacancy; or the physical or mental diseases cannot be cured.

To this problem, psychological assistance could adopt the relevant methods and technologies for psychological consulting and treatment, so as to eliminate the absolute view of pain in the minds of the cult followers, and make them stop believing in cult, and imaging that human being could cure all diseases in one morning and destroy death.

Psychological assistance could help people eliminate the inner fears. Fear is a hidden potential lesion deep in human being's psychology, and it is a psychological breakthrough for the cults to hunt for followers. Psychological assistance could eliminate the cult followers' fear of death through the modern psychology-related psychotherapies according to generation of fear emotion for the theory of "emotions generated from intelligence" which is restricted by the recognition activity.

Psychological assistance could help the cult followers eliminate the inner grudges and resentments. Generally speaking, grudges and resentments are the emotional state of not daring to anger or speak when facing unfairness and being bullied and oppressed, it is a psychological reaction of the weak when they are facing the helpless unfortunate fate, while most of the cult followers are weak groups, and the cult has known well their psychologies. On the one hand, it tries hard to defame the current society, and enhance their grudge and resentment emotions; on the other hand, it provides two channels for the followers to clear up such grudge and resentment emotions: The first one is to incite and lead the followers to attack and slander the Communist Party who is in power in China as well as its government; the second is to vigorously advocate cheap tickets of the Kingdom of Heaven, and make promise to lead them to a blissful world without contradictions.

Different from the cult, psychological assistance is to help the followers eliminate their grudges and resentments with its specific theories and methods:

Psychological assistance could reduce the cult followers' sense of emptiness and helplessness when they get rid of cult. Sense of emptiness is a kind of 
inner experience one suffers from big loss; sense of helplessness means a kind of inner experience that after one has suffered from frustrations or attacks, despite efforts in many ways, even struggles, they still cannot prevent the frustrations or attacks from befalling continuously, so that they have lost their motivations and desires to struggle for salvations, and completely stopped making efforts and struggling, but resigned themselves to their fates. Facing those people who are in sense of emptiness and helplessness in real life, cult will input the motivations and powers into them to seek another world and another tender and rich homeland, so as to make them believe in cult and practice with substantial psychology for the beautiful goals sketched for them by cult. However when they finally wake up from their dreams with the help of persuasion education and get rid of cult, they will come back into the conditions of emptiness, helplessness, and hopelessness before they entered the cult. At this time, psychological assistance is eagerly needed to be carried out on them and help them explore their potentials and learn to deal with frustrations and sufferings in real life.

Psychological assistance could help cult followers establish scientific philosophy of life. Psychological assistance could help them solve various puzzles and problems deep inside their thoughts and establish scientific philosophy of life, this is the important measure to prevent them from repeating their mistakes when they encounter disturbances or troubles in society, or suffer from frustrations and difficult positions and when the cults come back again.

Cult followers surely know well the activity trends and development situations of cults. When the psychological assistance personnel confidentially communicate and exchange with them with respectful, sincere, empathic, and positive attitude, they could obtain information about the cult and cult leaders in many ways, and this information is undoubtedly very necessary to prevent and resist the breeding and communication of cult.

\section{Specific Suggestions About Establishing Psychological Assistance System}

Train the psychological assistance personnel. Psychological assistance work should be undertaken by people with qualifications of psychological counselors and psychological therapists. According to what the authors know, since 2001, the China Ministry of Labor and Personnel had initiated the nationally recognized "psychological counselors" training, and trained a large number of qualified psychological counselors. What's more, psychology departments of more than 200 universities and colleges would supply graduates to society every year, and they are supposed to be the natural candidates for psychological assistance work. Therefore, there shall be no problem in the allocation of assistance personnel to establish the national psychological assistance system.

Location allocation. In cities, it is suggested to establish the "Psychological Assistance Center" in communities. At the present time, some one-step-ahead communities, for example, Shuiguohu Street of Wuchang District, Wuhan City has established the "Psychological Service Center"; in such communities, the "Psychological Assistance Center" could co-work with the "Psychological Service Center" or the "Community Correction Center". In the rural areas, the "Psychological Assistance Center" could be established in the health clinics in towns and townships and village clinics.

Comprehensive powers. Rural areas are still the key points to prevent and resist the breeding and communication of cult, in the recent years, the university graduates coming to rural areas to work as village officials is an important measure for the Communist Party to cultivate cadres at the basic level, therefore, the counties and cities could start several periods of training classes of psychological counselors focusing on the college students village officials, and let them master the knowledge and skills of psychological assistance, so as to fulfill the prevention 
and resistance work against the breeding and communication of cult as a part-time job in the mean time of working on the rural construction and development.

\section{References}

Eimuth, K. H. 2001. Anti-cult Manual. Translated by L. Lu. Beijing: Central Compilation \& Translation Press.

Gerrig, R. and P. Zimbardo. 2003. Psychology and Life. Beijing: Posts \& Telecom Press.

Guo, N. F. 2005. Psychological Counselors. Beijing: The Ethnic Publishing House.

Guo, Y. Y. and W. Wang. 2007. Psychological Guidance. Wuhan: Huazhong Normal University Press.

Hassan, S. 2001. Out of Cult. Translated by S. L. Yang and F. Yang. Hefei: Anhui Literature and Art Publishing House.

Hilgard, E. R. and R. C. Atkinson. 1987. Gateways to Psychology. Beijing: Beijing University Press.

Jiang, G. R. 2005. Theory and Practice of Psychological Counseling. Beijing: Higher Education Press.

Myers, D. 2006. Social Psychology. Beijing: Posts \& Telecom
Press.

Otto, R. 1995. The Idea of the Holy. Translated by Q. Cheng and B. X. Zhou. Chengdu: Sichuan Renmin Press.

Robbins, S. P. 1996. Organizational Behavior. Beijing: China Renmin University Press.

Rodriguez, P. 2001. Obsession With Cult-Nature, Prevention and Disposition of Cult. Translated by L. Shi. Beijing: Xinhua Publishing House.

Shi, R. H. 1998. Social Psychology. Hangzhou: Zhejiang Education Publishing House.

Yang, H. F. 2006. Principles of Psychological Consulting. Hangzhou: Zhejiang University Press.

\section{Bios}

Guiyang Xie, Ph.D., professor, graduate student supervisor of Psychology Department, Hubei University, Wuhan, China; research field: psychology.

Meifu Yan, Ph.D., professor of Psychology Department, Hubei University, Wuhan, China; research field: psychology.

Qizhen Liu, M.S., professor, graduate student supervisor of Psychology Department, Hubei University, Wuhan, China; research field: psychology. 